6

\title{
RESOLUÇÃO N. 125/2010 DO CONSELHO NACIONAL DE JUSTIÇA E A RESOLUÇÃO N. 118/2014 DO CONSELHO NACIONAL DO MINISTÉRIO PÚBLICO
}

O Conselho Nacional de Justiça instituiu a Resolução n. 125 de 2010 como Política Pública "de Tratamento Adequado dos conflitos de interesses no âmbito do Poder Judiciário".

Conforme Watanabe (2014, p. 4) foram três a grandes inovaçõos dessa Política Pública: "I - atualização do conceito de acesso à justiça; II - transformação da 'cultura da sentença para a cultura da pacificação' e III - qualidade dos serviços".

A Resolução n. 125/2010 do Conselho Nacional de Justiça ampliou o conceito de acesso à justiça para acesso a uma

(...) ordem jurídica justa, com a oferta dos métodos consensuais de resolução de conflitos, que passaram a serem chamados de métodos adequados, bem como com a possibilidade da oferta de serviços de cidadania, como orientação jurídica e certidōes. ${ }^{22}$

O novo paradigma vivenciado a partir da Resolução n. 125 do CNJ passa a ser a mudança da cultura da sentença, do processo, para uma cultura da busca pelo

22 Conforme o primeiro artigo da Resolução n. 125 do Conselho Nacional de Justiça: "Art. $1^{\circ}$ Fica instituída a Política Judiciária Nacional de tratamento dos conflitos de interesses, tendente a assegurar a todos o direito à solução dos conflitos por meios adequados à sua natureza e peculiaridade. Parágrafo único. Aos órgãos judiciários incumbe, além da solução adjudicada mediante sentença, oferecer outros mecanismos de soluçôes de controvérsias, em especial os chamados meios consensuais, como a mediação e a conciliação, bem assim prestar atendimento e orientação ao cidadão". Disponível em <http://www.cnj.jus.br/images/stories/docs_cnj/ resolucao/arquivo_integral_republicacao_resolucao_n_125.pdf >. Acesso em: 19 maio 2015. 
consenso e da pacificação, por meio da valorização e procura de uma solução amigável por meio de terceiros facilitadores, por meio da conciliação e da mediação e de outros meios adequados.

O terceiro pilar da Resolução n. 125 do CNJ fundamenta-se na preocupação com a oferta e qualidade dos serviços, traçando as diretrizes para como deve ser a capacitação, o treinamento e o aperfeiçoamento permanente dos conciliadores e mediadores.

Segundo Pereira Júnior, a Resolução n. 125 do CNJ:

cria os órgãos responsáveis pela política central de conciliação e mediação, e operacionaliza os braços executivos de tais políticas, os Centros Judiciários de Solução de Conflitos e Cidadania (2014, p. 32).

Fundamentada na Resolução n. 125 do Conselho Nacional de Justiça, em 2014 foi instituída a Resolução n. 118 do Conselho Nacional do Ministério Público que "dispõe sobre a Política Nacional de Incentivo à Autocomposição no âmbito do Ministério Público" e recomenda:

Negociação: nos conflitos em que o órgão atue como parte, na defesa dos direitos e interesses da sociedade; mediação: para resolver conflitos que envolvam relações jurídicas nas quais é importante a direta e voluntária ação de ambas as partes divergentes; conciliação: nos casos que envolvam direitos ou interesses nas áreas de atuação do Ministério Público como órgão interveniente (quando do seu parecer sobre normas legais, sem ser parte). 